Uşak Üniversitesi Sosyal Bilimler Dergisi

$2014,7 / 2$

\title{
Üniversite Öğrencilerinin Kırşehir'in Tarihi ve Kültürel Turizm Değerlerine Yönelik Farkındalıkları*
}

\author{
Selman ABLAK ${ }^{*}$ \\ Yurdal DÍKMENLI' ${ }^{* * * *}$ \\ Turhan ÇETIN ${ }^{* * *+4}$
}

\begin{abstract}
Özet
Bu araştırmanın amacı, Kırşehir Ahi Evran Üniversitesi, Eğitim Fakültesi, Sosyal Bilgiler Eğitimi Ana Bilim Dalı ve Sınıf Öğretmenliği Ana Bilim Dalı'nda öğrenim gören 1., 2., 3. ve 4. sınıftaki öğretmen adaylarının Kırşehir ilinde bulunan tarihî ve kültürel turizm değerleri hakkındaki tutumlarını farklı değişkenler açısından belirlemektir. Nicel araştırma yöntemiyle verilerin toplandığı bu çalışma betimsel bir alan araştırmasıdır. Araştırma, çalışma grubunda yer alan 205 sınıf öğretmen adayı ve 118 sosyal bilgiler öğretmen adayı olmak üzere toplam 323 öğretmen adayı ile gerçekleştirilmiştir. Araştırma bulgularından ulaşılan sonuçlara göre; sosyal bilgiler öğretmenliği anabilim dalında öğrenim gören öğretmen adaylarının sınıf öğretmenliği anabilim dalında öğrenim gören öğretmen adaylarına göre tutum puanları daha yüksek çıkmıştır. Ayrıca 4. Sınıfta öğrenim gören öğretmen adaylarının diğer sınıflarda öğrenim gören adaylara nazaran tutum puanlarının daha yüksek olduğu görülmüştür.
\end{abstract}

Anahtar Kelimeler: Tarihî ve Kültürel Değerler, Sosyal Bilgiler Öğretmen Adayları, Sınıf Öğretmenliği Öğretmen Adayları, Tutum.

\section{The Awareness Levels Of The University Students About The Historical And Touristic Values Of Kırşehir}

\begin{abstract}
The goal of this study was to elucidate the attitudes of 1th-4th year preservice teachers studying in Social Sciences and Primary Education departments of Kırşehir Ahi Evran University about the historical and cultural values of Kırşehir as regards to various parameters. This is a descriptive field study where the data were collected by the qualitative

\footnotetext{
* Çalışmanın bir bölümü 3-5 Ekim 2013 tarihleri arasında Trabzon'da düzenlenen VI. Sosyal Bilimler Eğitimi Kongresi'nde" sözlü bildiri olarak sunulmuştur.

** Arş.Gör., Gazi Üniversitesi, Gazi Eğitim Fakültesi, Sosyal Bilgiler Eğitimi ABD

*** Öğr. Gör. Dr., Ahi Evran Üniversitesi, Eğitim Fakültesi Sınıf Öğretmenliği ABD

**** Doç. Dr., Gazi Üniversitesi, Gazi Eğitim Fakültesi, Sosyal Bilgiler Eğitimi ABD
} 
survey method. The study was carried out 205 primary and 118 social studies total of 323 pre service teachers. The resulting data revealed that the students studying in the social studies department had scored higher points in the attitude scale compared to the students studying in the primary education department. It was also observed that the attitude point of the 4th year students were higher than the others.

Key words: Cultural and Historical Values; Social Studies Pre-Service Teachers; Primary Education Pre-Service Teachers; Attitude.

\section{Giriş}

Turizm, çok boyutlu bir kavram olmakla beraber en genel tanımıla insanların kültür, dinlenme, sağlık, spor, avlanma, gezme, kongre, diğer toplum ve toplulukları tanıma gibi amaçlarla bulundukları yerlerden ayrılarak geçici süre ile yurt içi ve yurt dışı bölgelere gitmeleri olarak tanımlanabilir (Soykan, 2004: 6, Kahraman ve Türkay, 2006: 1, Doğanay, 2001: 15, Özgüç, 2003:3, Sezgin, 1995:4, Ürger, 1992: 11). Dünyada özellikle 1960'l1 yıllarla birlikte büyük bir gelişme gösteren turizm ve bağlamında turizm sektörü ülkemizde de benzer bir ilerleme kaydetmiştir. Turizmin ülke ekonomilerine yapmış olduğu katkı sürekli bir artış göstermektedir (Ehtiyar ve Üngüren, 2008: 160). Ülkelerde turizmden elde ettikleri pay1 artırmak adına her geçen gün yeni politikalar geliştirmekte ve hayata geçirmektedirler. Dünya ülkeleri gelir ve istihdam yaratma açısından önemli etkilere sahip bu sektörü canlandırabilmek için yüksek miktarlarda harcamalar yapmaya başlamıştır (Yıldız ve Kalağan, 2005: 42). Bu noktada ülkemiz de sektörden yararlanıp ekonomisine katkı sağlamak amacıyla kendi yönünü belirlemeye başlamıştır (Emekli, 1998: 2). Bu çalışmaların yanı sıra ulaştırma araçlarında sürekli gelişme ve artan refah seviyesi ile sektörün gelişmesini artarak sürdüreceği düşünülmektedir. Özellikle ulaşım kolaylıkları insanların gezip görme ve dinlenme, yani seyahat alışkanlıklarını hem değiştirmiş hem de artırmıştır (Bulu ve Eraslan, 2008). Bununla beraber gerek dünyada gerekse ülkemizde turizm denilince oluşan algı, değişmeye başlamış; alternatif turizm kolları hayat bulmuştur.

Deniz, kum ve güneşe dayanan kıyı turizmi önemini devam ettirmekle birlikte son yıllarda turistik talepteki değişmeler dikkat çekici bir boyut kazanmaktadır (Emekli, 2005: 101). İnsanlar sadece dinlenme amaçlı tatil yapmak yerine dinlenirken öğrenme, farklı kültürleri tanıma ve geçmişin izlerine şahit olma gibi amaçlar taşımaktadırlar. Bu istek doğrudan tarihi ve kültürel turizm kavramını ortaya çıkarmıştır. Kültürel turizm 
festival, folklor, tiyatro, sergi gibi sanat etkinliklerine katılmak, geçmiş ve yaşayan uygarlıklar ile kültürel değerleri tanımak, tarihi yerleri ve toplumun yaşam tarzlarını görmek, dini ziyaret gibi kültürel motivasyonlarla kişilerin hareket etmesi amacıyla yapılan gezi olarak tanımlanmaktadır. (Aydın, 1990: 27; Kozak vd., 2011; Çetin, 2010: 182). Bir ülkenin otantikliğini-özgünlüğünü en rahat şekilde ortaya koyabileceği kavram kültürel turizmdir (Usta, 2012:163). Yapılan çalışmalarda kültürel turizm kavramının yanı sıra kültür turizmi, tarihi turizm, miras turizmi gibi kavramlar da kullanılmaktadır (Doğaner, 2003:3). Ancak bilinmektedir ki kültürel turizm farklı isimler altında anılsa da tabii bir şekilde hızlı bir gelişim göstermektedir. Bu gelişmeden faydalanmak ülkelerin turizm adına yeni hedeflerini oluşturmaktadır. Bu durum ülkemiz açısından daha bir önem arz etmektedir. Anadolu'nun dünya tarihi boyunca birçok uygarlığın doğuşuna, gelişmesine ve çöküşüne sahne olduğunu ve son derece zengin tarihi ve arkeolojik değerlere sahip olduğu bilinmektedir (Barutçugil, 1986: 68). Türkiye'nin üzerinde bulunduğu coğrafya dünyanın en eski uygarlıklarına ev sahipliği yapmış olup, gün yüzüne çıkarılan kültürel zenginliklerimiz göz kamaştırmaktadır (Tok, 2002: 221). Dünyada eşi benzeri olmayan zenginliklere, medeniyetlere beşiklik etmiş Anadolu topraklarında Hititler, Urartular, Likyalılar, Lidyalılar, Frigyalılar, İyonlar, Romalılar, Bizanslılar, Selçuklular, Osmanlılar, Türkiye Cumhuriyeti'ne gelinceye kadar birçok iz ve kalıntı bırakarak, ülkemizi benzersiz bir konuma ulaştırmışlardır (Doğaner, 2001). Bütün bu değerler ülkemizin doğal, tarihi ve kültürel mirası niteliğindedir. Doğal ve kültürel miras, tarih öncesi ve tarihi devirlere ait bilim, kültür, din ve güzel sanatlarla ilgili bulunan yer altı, yerüstü veya su altındaki tüm taşınır taşınmaz varlıklar olarak tanımlanabilir (Doğaner 2001: 135; Oğuz 2007:7). Tarihi, arkeolojik, kentsel ve doğal sitler, anıt, ören yeri, höyük, tümülüs, külliye, cami, kilise gibi somut kültür kalıntıları kültürel mirası oluşturur (Çetin, 2010: 182).

Zengin doğal, tarihi ve kültürel mirasımız ve turizm açısından düşündüğümüzde tüm bu kültürel turizm öğelerimiz ülkemizin turizm potansiyelinde büyük bir önem arz etmektedir. Ülkeler için önemli bir alternatif turizm türü olan kültür turizmi, gelir sağlayıcı etkisinin yanında kültürel değerlerin korunması açısından da üzerinde durulan bir turizm şekli olarak tanımlanabilir (Öztürk vd., 2002:189). Söz konusu kültürel değerlerin gelecek kuşaklara aktarılması için, özellikle tarihî çevrenin korunması, geliştirilmesi ve tarihî çevre içinde yer alan değerlerin turizm amaçlı kullanımlarının sağlanması doğrultusunda, kültürel varlıklara gerekli önemin verilmesi dikkat edilmesi gereken bir konudur (Meydan Uygur ve Baykan, 2007: 46). Şüphesiz bu dikkatin sağlanması için gerekli 
olan şey, bireylere verilecek olan tarihi ve kültürel değerlere yönelik eğitimdir. $\mathrm{Bu}$ sayede bireyler tarihi ve kültürel değerlerin farkına varabilecek, koruyup-geleceğe aktarabilecek ve bu değerlerden ekonomik olarak turizm sektöründe faydalanabilecektir. Bunu sağlayacak olan da öğretmenler ve bu bağlamda öğretmen adaylarıdır. Bu anlamda kendilerine genç nesilleri yetiştirme görevi verilecek olan öğretmen adaylarının tarihi ve kültürel turizme yönelik tutumlarının olumlu yönde olması ve söz konusu değerlere ilişkin farkındalıkları önem taşımaktadır (Dinç, Erdil ve Keçe, 2011; Keçe ve Dinç, 2010). Buradan hareketle ülkemizin sahip olduğu tarihi ve kültürel turizm değerlerine yönelik bireylerin tutumları, bu değerlerin varlığının korunup sürdürülebilmesi ve gelecek nesillere aktarılması açısından önem taşımaktadır.

Literatür incelendiğinde; Kırşehir'de termal turizm varlığı (Karakuş ve Çetin, 2003) ve turizm potansiyeline (www.kirsehirkulturturizm.gov.tr, 2013) ait yeterli araştırma olmadığı ancak, öğrencilerin turizme ilişkin görüşlerinin incelendiği bazı araştırmaların (Alkış ve Oğuzoğlu, 2005; Gümüş ve Özüpekçe 2009; Keçe ve Dinç 2010; Dinç vd. 2011; Karakuş vd. 2011; İncekara ve Savran 2011) olduğu görülmektedir.

\section{Yöntem}

\section{Araştırma Modeli}

$\mathrm{Bu}$ çalışma nicel araştırma yöntemini esas alan, genel tarama modelinde yapılandırılmıştır. Tarama modelleri, geçmişte ya da halen var olan bir durumu var olduğu şekliyle betimlemeyi amaçlayan bir araştırma yaklaşımı olarak tanımlanabilir (Karasar, 2011: 77).

\section{Çalışma Grubu}

Bu çalışma 2012-2013 öğretim yılında Ahi Evran Üniversitesi Eğitim Fakültesi Sosyal Bilgiler Öğretmenliği ve Sınıf Öğretmenliği Ana Bilim Dalı 1., 2., 3. ve 4. sınıfta öğrenim gören öğretmen adayları üzerinde yapılmıştır. $\mathrm{Bu}$ kapsamda random (tesadüfi) örneklem yöntemi kullanılarak 323 öğretmen adayının görüşleri alınmıştır.

\section{Veri Toplama Aracı ve Uygulama}

Çalışmada öğretmen adaylarının görüşlerini almak için araştırmacılar tarafından geliştirilen veri toplama aracı kullanılmıştır. Veri toplama aracı olarak kullanılan ölçeğin geliştirilme aşamasında öncelikle literatür taraması yapılmış ve ölçek maddeleri oluşturulmuştur. Alınan uzman görüşleri doğrultusunda ölçek maddeleri üzerinde gerekli düzeltmeler yapıldıktan sonra, ölçeğin ön uygulaması yapılmıştır. Bu 
aşamada hazırlanan form öncelikle farklı sınıflarda öğrenim gören 83 sosyal bilgiler öğretmen adayı ve 112 sınıf öğretmen adayı üzerinde uygulanmıştır. Ön uygulama verileri üzerinde yapılan analiz sonrasında soru formu düzenlenerek geri kalan 10 madde ön uygulama yapılan öğrencilerin dışında 323 öğretmen adayı üzerinde uygulanmıştır.

\section{Verilerin Analizi}

Yapılan ön uygulama, aşamasından sonra nihai kalan 10 madde üzerinde yapılan Cronbach Alpha güvenirlik katsayısı incelenmiş ve ölçeğin güvenirliği .75 olarak saptanmıştır. Büyüköztürk'e (2007) göre güvenirlik katsayısının .70 ve üzeri olduğu durumlarda ölçek güvenilir olarak değerlendirilmektedir.

Anketlerin uygulanmasından sonra SPSS 20.00 paket programı kullanılarak elde edilen verilerin analizinde t-testi ve tek yönlü varyans analizi yapılmıştır. Yapılan tek yönlü varyans analizinde anlamlılı̆̆ın hangi guruplar lehine olduğunu belirlemek için Tukey HSD testi yapılmıştır.

\section{Bulgular ve Yorumlar}

Bu bölümde sınıf ve sosyal bilgiler öğretmen adaylarının tarihî ve kültürel turizm değerlerine ilişkin tutum ve düşüncelerinin bölüm, cinsiyet, sınıf, ikamet edilen yer gibi değişkenler açısından görüşlerini yansıtan bulgulara ve yorumlara yer verilmiştir.

Tablo 1. Katılımcıların Bölümlerine Göre Dă̆̆llımları

\begin{tabular}{|c|c|c|}
\hline Bölüm & $\mathrm{f}$ & $\%$ \\
\hline Sınıf Öğretmenliği & 205 & 63,5 \\
\hline $\begin{array}{l}\text { Sosyal } \\
\text { Öğretmenliği }\end{array}$ & 118 & 36,5 \\
\hline Toplam & 323 & 100,0 \\
\hline
\end{tabular}

Tablo 1'de görüldüğü üzere çalışmaya katılan öğretmen adaylarının 205'ini (\%63.5) sınıf öğretmeni adayları oluştururken, 118'ini (\%36.5) sosyal bilgiler öğretmeni adayı oluşturmaktadır.

Tablo 2. Çalışmaya Katılan Öğretmen Adaylarının Cinsiyete Göre Dağılımları 


\begin{tabular}{lcc}
\hline Cinsiyet & $\mathrm{f}$ & $\%$ \\
Erkek & 111 & 34.4 \\
Kadın & 212 & 65,6 \\
Toplam & 323 & 100,0 \\
\hline
\end{tabular}

Tablo 2'de görüldüğü üzere araştırmaya toplam 323 öğretmen adayı katılmıştır. Bunların 111'i (\%34.4) erkek, 212'si (\%65.6) kadın öğretmen adayıdır.

Tablo 3. Çalışmaya Katılan Öğretmen Adaylarının Sınıf Düzeyine Göre Dağılımları

\begin{tabular}{lcc}
\hline Sinif & $\mathrm{f}$ & $\%$ \\
1.Sinif & 73 & 22,6 \\
2.Sinif & 94 & 29,1 \\
3.Sinif & 89 & 27,6 \\
4.Sinif & 67 & 20,7 \\
Toplam & 323 & 100,0 \\
\hline
\end{tabular}

Tablo 3'deki bulgular incelendiğinde çalışmaya katılan toplam 323 öğretmen adayının 73'ünü (\%22.6) 1. Sınıf öğrencileri, 94'ünü (\%29.1) 2.sınıf öğrencileri, 89'unu (\%27.6). 3.sınıf öğrencileri ve 67'sini (\%20.7) 4.sınıf öğrencileri oluşturmaktadır. Buna göre araştırmaya katılanların dengeli (homojen) dağılım gösterdikleri söylenebilir.

Tablo 4. Çalışmaya Katılan Öğretmen Adaylarının Ailelerinin İkamet Ettikleri Yere Göre Dağılımı

\begin{tabular}{lcc}
\hline Aile İkamet Yeri & $\mathrm{f}$ & $\%$ \\
Köy & 49 & 15,2 \\
Kasaba- Belde & 34 & 10,5 \\
& & \\
İlçe Merkezi & 92 & 28,5 \\
İl Merkezi & 148 & 45,8 \\
Toplam & 323 & 100,0 \\
\hline
\end{tabular}

Tablo 4'de görüldüğü üzere çalışmaya katılan 323 öğretmen adayının ailelerinin 49'u (15.2) köy, 34'ü (\%10.5) kasaba-belde, 92'si (\%28.5) ilçe merkezi ve 148'i (\%45.8) il merkezinde ikamet etmektedir. 
Tablo 5. Katılımcıların Tarihî ve Kültürel Turizm Değerlerine Yönelik Tutum Toplam Puanlarının Bölüm Değişkenine Göre t-testi Sonuçlarn

\begin{tabular}{lllllll} 
Bölüm & $\mathrm{N}$ & $\overline{\mathrm{X}}$ & $\mathrm{S}$ & $\mathrm{sd}$ & $\mathrm{t}$ & $\mathrm{p}$ \\
\hline Sinif & 205 & 34,04 & 4,32 & & & \\
\hline Sosyal & 118 & 35,55 & 5,44 & & & \\
\hline $\mathrm{p}<0.05$ & & & & & &
\end{tabular}

Tablo'5'e göre çalışma grubundaki sınıf öğretmenliği programında öğrenim gören öğretmen adaylarının tarihî ve kültürel değerlere yönelik tutum toplam puanlarının aritmetik ortalamasının $\overline{\mathrm{X}}=34.04$; sosyal bilgiler öğretmenliği programında öğrenim gören öğretmen adaylarının aritmetik ortalamasının ise $\overline{\mathrm{X}}=35,55$ olduğu görülmektedir. Öğretmen adaylarının tarihî ve kültürel değerlere ilişkin tutum toplam puanları aritmetik ortalaması ile öğrenim gördükleri bölüm değişkenleri arasındaki ilişki incelenmiş ve sosyal bilgiler öğretmenliği programında öğrenim görenlerin lehine anlamlı farklılık olduğu tespit edilmiştir $\left(t_{(321)}=2,739 ; \quad p<.05\right)$. Dolayısıyla sosyal bilgiler öğretmenliği programında öğrenim gören katılımcıların tarihî ve kültürel değerlerle yönelik tutumlarının daha üst seviyede olduğu söylenebilir.

Tablo 6. Katılımcıların Tarihî ve Kültürel Turizm Değerlerine Yönelik Tutum Toplam Puanlarının Cinsiyet Değişkenine Göre t-testi Sonuçları

\begin{tabular}{|c|c|c|c|c|c|c|}
\hline Cinsiyet & $\mathrm{N}$ & $\bar{x}$ & $S$ & $\mathrm{sd}$ & $\mathrm{t}$ & $p$ \\
\hline erkek & 111 & 34,67 & 4,96 & & & \\
\hline kadın & 212 & 34,56 & 4,74 & & & \\
\hline
\end{tabular}

$\mathrm{p}<0.05$

Tablo 6'ya göre çalışma grubundaki erkek öğretmen adaylarının tarihî ve kültürel değerlere yönelik tutum toplam puanlarının aritmetik ortalamasının $\overline{\mathrm{X}}=34,67$; kadın öğretmen adaylarının aritmetik ortalamasının ise $\overline{\mathrm{X}}=34,56$ olduğu görülmektedir. Öğretmen adaylarının tarihî ve kültürel değerlere ilişkin tutum toplam puanları aritmetik ortalaması ile cinsiyetleri arasındaki ilişki incelenmiş ve anlamlı bir farklılık gözlenmemiştir $\left(t_{(321)}=, 195 ; p>.05\right)$. Bu bulgu katılımcıların tarihî ve kültürel değerlerle 
yönelik tutumlarında cinsiyet faktörünün belirli bir etkiye sahip olmadığı şeklinde yorumlanabilir.

Tablo7. Katılımcıların Tarihî ve Kültürel Turizm Değerlerine Yönelik Tutum Toplam Puanlarının Sınıf Değgişkenine Göre Farklılı̆̆ı İçin Tek Yönlü Varyans Analizi (ANOVA) Sonuçları

\begin{tabular}{|c|c|c|c|c|c|c|c|}
\hline Değişken & & & & $\mathrm{N}$ & $\overline{\mathrm{X}}$ & & $S$ \\
\hline \multirow{8}{*}{ Sinif } & $1 \mathrm{sinif}$ & & & 73 & 33,84 & & 4,16 \\
\hline & 2 sinif & & & 94 & 33,69 & & 5,07 \\
\hline & 3 sinif & & & 89 & 35,30 & & 4,59 \\
\hline & 4 sinif & & & 67 & 35,75 & & 5,08 \\
\hline & $\begin{array}{l}\text { Varyansın } \\
\text { Kaynağ1 }\end{array}$ & KT & sd & $\mathrm{KO}$ & $\mathrm{F}$ & $\mathrm{p}$ & Tukey \\
\hline & $\begin{array}{l}\text { Gruplar } \\
\text { Arasi }\end{array}$ & 252,294 & 3 & 84,098 & 3,729 & ,012 & \multirow{3}{*}{$\begin{array}{l}2 . \\
\text { sinif- } \\
4 . \\
\text { sinif }\end{array}$} \\
\hline & $\begin{array}{l}\text { Gruplar } \\
\text { İçi }\end{array}$ & 7193,576 & 319 & 22,550 & & & \\
\hline & Toplam & 7445,870 & 322 & & & & \\
\hline
\end{tabular}

Tablo 7'deki analiz sonuçlarına göre, katılımcıların Tarihî ve Kültürel Turizm Değerlerine Yönelik Tutum toplam puanların ile öğrenim gördükleri sinıf düzeyi değişkeni arasında anlamlı bir farklılık gözlenmiştir $\left[\mathrm{F}_{(3-319)}=3.729\right.$; $\mathrm{p}<$,05]. Bu farklılığın hangi gruplar arasında olduğunu görmek için Tukey çoklu karşılaştırma testi yapılmıştır. Bu sonuçlara göre 2. Sınıftaki katılımcıların Tariĥ̂ ve Kültürel Turizm Değerlerine Yönelik Tutum toplam puanları ortalaması $(\bar{X}=33,69)$ ile 4 . Sinıftaki katılımcıların Tarihî ve Kültürel Turizm Değerlerine Yönelik Tutum toplam puanları ortalaması ( $\overline{\mathrm{X}}=35,75)$ arasında, 4. Sınıftaki katılımcıların lehine anlamlı bir farklılık bulunmuştur. Bu bulgu; 4. Sınıftaki katılımciların, 2. Sınıfta olan katılımcilara göre Tarihî ve Kültürel Turizm Değerlerine Yönelik görüşlerinin daha olumlu olduğu şeklinde yorumlanabilir. Bu durumda 4. Sinıfta öğrenim gören katılımcıların Kırşehir'de iki yıl daha fazla yaşamaları nedeniyle ildeki turizm değerlerini daha fazla gördükleri söylenebilir.

Tablo 8. Katılımcıların Tarihî ve Kültürel Turizm Değerlerine Yönelik Tutum Toplam Puanlarının Ailenin İkamet Ettiği Yerleşim Birimi 
Değişkenine Göre Farklılığı İçin Tek Yönlü Varyans Analizi (ANOVA) Sonuçları

\begin{tabular}{|c|c|c|c|c|c|c|c|}
\hline Değişken & & & & $\mathrm{N}$ & $\overline{\mathrm{X}}$ & & $S$ \\
\hline \multirow{7}{*}{$\begin{array}{l}\text { Ailenin } \\
\text { İkamet } \\
\text { Ettiği } \\
\text { Yerleşim } \\
\text { Birimi }\end{array}$} & \multicolumn{3}{|l|}{ Köy } & 49 & \multicolumn{2}{|c|}{35,06} & 5,25 \\
\hline & \multicolumn{3}{|c|}{ Kasaba/Belde } & 34 & \multicolumn{2}{|c|}{34,15} & 4,43 \\
\hline & \multicolumn{3}{|c|}{ İlçe Merkezi } & 92 & \multicolumn{2}{|c|}{34,78} & 5,18 \\
\hline & \multicolumn{3}{|c|}{ İl Merkezi } & 148 & \multicolumn{2}{|c|}{34,43} & 4,53 \\
\hline & $\begin{array}{l}\text { Varyansın } \\
\text { Kaynağ1 }\end{array}$ & $\mathrm{KT}$ & sd & $\mathrm{KO}$ & $\mathrm{F}$ & $\mathrm{p}$ & Tukey \\
\hline & $\begin{array}{l}\text { Gruplar } \\
\text { Arasi }\end{array}$ & 24,954 & 3 & 8,318 & ,358 & ,784 & \\
\hline & $\begin{array}{l}\text { Gruplar } \\
\text { İçi }\end{array}$ & 7420,916 & 319 & 23,263 & & & - \\
\hline & Toplam & 7445,870 & 322 & & & & \\
\hline
\end{tabular}

Tablo 8'deki analiz sonuçlarına göre, katılımcıların Tarihî ve Kültürel Turizm Değerlerine Yönelik Tutum toplam puanların ile ailenin ikamet ettiği yerleşim birimi değişkeni arasında anlamlı bir farklılık gözlenmemiştir $\left[\mathrm{F}_{(3-319)}=, 358\right.$; $\mathrm{p}>$,05]. Bu bulgu; katılımcların Tarihî ve Kültürel Turizm Değerlerine Yönelik görüşlerinde ailelerinin ikamet ettiği yerleşim biriminin herhangi bir etkiye sahip olmadığı şeklinde yorumlanabilir.

Tablo 9. Katılımcıların Tarihı̂ ve Kültürel Turizm Değerlerine Yönelik Tutum Toplam Puanlarının Anne Ĕ̆itim Durumu Değişkenine Göre Farkhlı̆̆ı İçin Tek Yönlü Varyans Analizi (ANOVA) Sonuçları

\begin{tabular}{|c|c|c|c|c|c|c|c|}
\hline Değişken & & & & $\mathrm{N}$ & $\overline{\mathrm{X}}$ & & $S$ \\
\hline \multirow{8}{*}{$\begin{array}{l}\text { Anne } \\
\text { Eğitim } \\
\text { Durumu }\end{array}$} & İlkokul & & & 211 & 34,54 & & 4,76 \\
\hline & Orta Okul & & & 57 & 35,07 & & 5,18 \\
\hline & Lise & & & 45 & 34,42 & & 5,01 \\
\hline & Üniversite & & & 10 & 33,90 & & 2,60 \\
\hline & $\begin{array}{l}\text { Varyansın } \\
\text { Kaynağ1 }\end{array}$ & $\mathrm{KT}$ & $\mathrm{sd}$ & $\mathrm{KO}$ & F & $\mathrm{p}$ & Tukey \\
\hline & $\begin{array}{l}\text { Gruplar } \\
\text { Arasi }\end{array}$ & 19,789 & 3 & 6,596 & 283 & 837 & \multirow{3}{*}{ - } \\
\hline & $\begin{array}{l}\text { Gruplar } \\
\text { İçi }\end{array}$ & 7426,080 & 319 & 23,279 & & & \\
\hline & Toplam & 7445,870 & 322 & & & & \\
\hline
\end{tabular}


Tablo 9'daki analiz sonuçlarına göre, katılımcıların Tarihî ve Kültürel Turizm Değerlerine Yönelik Tutum toplam puanların ile anne eğitim durumu değişkeni arasında anlamlı bir farkl1lık gözlenmemiştir $\left[\mathrm{F}_{(3-319)}=, 283 ; \mathrm{p}>, 05\right]$. $\mathrm{Bu}$ bulgu; katılımcların Tariĥे ve Kültürel Turizm Değerlerine Yönelik görüşlerinde anne eğitim durumu değişkeninin bir etkiye sahip olmadı̆̆ 1 şeklinde yorumlanabilir.

Tablo 10. Katılımcılarn Tarihî ve Kültürel Turizm Değerlerine Yönelik Tutum Toplam Puanlarının Baba Eğitim Durumu Değişkenine Göre Farklılığı İçin Tek Yönlï Varyans Analizi (ANOVA) Sonuçları

\begin{tabular}{|c|c|c|c|c|c|c|c|}
\hline Değişken & & & & $\mathrm{N}$ & $\overline{\mathrm{X}}$ & & $S$ \\
\hline \multirow{8}{*}{$\begin{array}{l}\text { Baba } \\
\text { Eğitim } \\
\text { Durumu }\end{array}$} & İlkokul & & & 137 & 34,88 & & 4,69 \\
\hline & Orta Okul & & & 75 & 34,17 & & 5,14 \\
\hline & Lise & & & 68 & 33,96 & & 4,93 \\
\hline & Üniversite & & & 43 & 35,42 & & 4,33 \\
\hline & $\begin{array}{l}\text { Varyansın } \\
\text { Kaynağ1 }\end{array}$ & $\mathrm{KT}$ & $\mathrm{sd}$ & $\mathrm{KO}$ & F & $\mathrm{p}$ & Tukey \\
\hline & $\begin{array}{l}\text { Gruplar } \\
\text { Arası }\end{array}$ & 81,659 & 3 & 27,220 & 1,179 & ,318 & \\
\hline & $\begin{array}{l}\text { Gruplar } \\
\text { İçi }\end{array}$ & 7364,211 & 319 & 23,085 & & & - \\
\hline & Toplam & 7445,870 & 322 & & & & \\
\hline
\end{tabular}

Tablo 10'daki analiz sonuçlarına göre, katılımcıların Tarihî ve Kültürel Turizm Değerlerine Yönelik Tutum toplam puanların ile baba eğitim durumu değişkeni arasında anlamlı bir farklılık gözlenmemiştir $\left[\mathrm{F}_{(3-319)}=\right.$ 1,179; p ,05]. Bu bulgu; katılımcıların Tarihî ve Kültürel Turizm Değerlerine Yönelik görüşlerinde baba eğitim durumu değişkeninin bir etkiye sahip olmadığı şeklinde yorumlanabilir.

Tablo 11. Katılımcıların Tarihî ve Kültürel Turizm Değerlerine Yönelik Tutum Toplam Puanlarının Lisans Ĕ̆itiminde Turizmle İlgili Ders Alma Durumu Değişkenine Göre t-testi Sonuçları

\begin{tabular}{lrlllll} 
Ders & Alma N & $\overline{\mathrm{X}}$ & $\mathrm{S}$ & $\mathrm{sd}$ & $\mathrm{t}$ & $\mathrm{p}$ \\
\hline \multirow{2}{*}{ Evet } & 40 & 35,25 & 5,01 & 321 &, 921 &, 358 \\
\hline
\end{tabular}


Sosyal Bilimler Dergisi 181

\begin{tabular}{lllllll} 
Ders & Alma N & $\overline{\mathrm{X}}$ & $\mathrm{S}$ & $\mathrm{sd}$ & $\mathrm{t}$ & $\mathrm{p}$ \\
\cline { 1 - 4 } Evet & 40 & 35,25 & 5,01 & \multirow{2}{*}{321} &, 921 &, 358 \\
\cline { 1 - 4 } Hayir & 283 & 34,50 & 4,78 & & &
\end{tabular}

$\mathrm{p}<0.05$

Tablo 11'e göre çalışma grubundaki lisans eğitiminde turizmle alakalı ders alan öğretmen adaylarının tarihî ve kültürel değerlere yönelik tutum toplam puanlarının aritmetik ortalamasının $\overline{\mathrm{X}}=35,25$; lisans eğitiminde turizmle ilgili ders almayan öğretmen adaylarının tarihî ve kültürel değerlere yönelik tutum toplam puanlarının aritmetik ortalamasının ise $\overline{\mathrm{X}}=34,50$ olduğu görülmektedir. Öğretmen adaylarının tarihî ve kültürel değerlere ilişkin tutum toplam puanları aritmetik ortalaması ile lisans eğitiminde turizmle ilgili ders alma durumu arasındaki ilişki incelenmiş ve anlamlı bir farklılık gözlenmemiştir $\left(\mathrm{t}_{(321)}=, 921 ; \mathrm{p}>\right.$.05). Bu bulgu katılımcıların tarihî ve kültürel değerlerle yönelik tutumlarında lisans eğitiminde turizmle ilgili ders alma durumu faktörünün belirli bir etkiye sahip olmadığı şeklinde yorumlanabilir.

Tablo 12. Katılımcıların Tarihî ve Kültürel Turizm Değerlerine Yönelik Tutum Toplam Puanlarının Lisans Eğitiminde Turizm İle İlgili Sunum, Ödev, Proje vb. Çalışma Hazırlama Durumu Değişkenine Göre t-testi Sonuçları

\begin{tabular}{|c|c|c|c|c|c|c|}
\hline $\begin{array}{l}\text { Ödev, Proje } \\
\text { Vb. Çalışma } \\
\text { Hazırlama }\end{array}$ & & $\overline{\mathrm{X}}$ & $S$ & $\mathrm{sd}$ & $t$ & $\mathrm{p}$ \\
\hline Evet & 63 & 34,63 & 5,05 & & & \\
\hline Hayır & 260 & 34,58 & 4,77 & & & \\
\hline
\end{tabular}

Tablo12'ye göre çalışma grubundaki lisans eğitiminde turizmle ilgili sunum, ödev, proje vb. çalışma hazırlayan öğretmen adaylarının tarihî ve kültürel değerlere yönelik tutum toplam puanlarının aritmetik ortalamasının $\overline{\mathrm{X}}=34,63$; lisans eğitiminde turizmle ilgili sunum, ödev, proje vb. çalışma hazırlamayan öğretmen adaylarının tarihî ve kültürel değerlere yönelik 
tutum toplam puanlarının aritmetik ortalamasının ise $\bar{X}=34,58$ olduğu görülmektedir. Öğretmen adaylarının tarihî ve kültürel değerlere ilişkin tutum toplam puanları aritmetik ortalaması ile lisans eğitiminde turizmle ilgili sunum, ödev, proje vb. çalışma hazırlama durumu arasındaki ilişki incelenmiş ve anlamlı bir farklılık gözlenmemiştir $\left(t_{(321)}=, 074 ; p>.05\right)$. Bu bulgu katılımcıların tarihî ve kültürel değerlerle yönelik tutumlarında lisans eğitiminde turizmle ilgili sunum, ödev, proje vb. çalışma hazırlama faktörünün belirli bir etkiye sahip olmadığı şeklinde yorumlanabilir.

Tablo 14. Katılımcılarn Tarihî ve Kültürel Turizm Değerlerine Yönelik Tutum Toplam Puanlarının Öğrenim Görülen Anabilim Dalında Kırşehir ve Yöresine Yönelik Gezi Düzenleme Durumu Değişkenine Göre t-testi Sonuçları

\begin{tabular}{lllllll}
$\begin{array}{l}\text { Gezi } \\
\text { Düzenleme } \\
\text { Durumu }\end{array}$ & $\mathrm{N}$ & $\overline{\mathrm{x}}$ & $\mathrm{S}$ & $\mathrm{sd}$ & $\mathrm{t}$ & $\mathrm{p}$ \\
\hline Evet & 166 & 34,84 & 4,87 & & & \\
\hline Hayır & 157 & 34,34 & 4,74 & 321 &, 933 &, 351 \\
\hline $\mathrm{p}<0.05$ & & & & & & \\
\hline
\end{tabular}

Tablo 14'e göre çalışma grubundaki öğretmen adaylarından öğrenim gördükleri anabilim dalında Kırşehir ve yöresine yönelik gezi düzenlenenlerin tarihî ve kültürel değerlere yönelik tutum toplam puanlarının aritmetik ortalamasının $\overline{\mathrm{X}}=34,84$; öğrenim gördükleri anabilim dalında Kırşehir ve yöresine yönelik gezi düzenlenmeyenlerin tarihî ve kültürel değerlere yönelik tutum toplam puanlarının aritmetik ortalamasının ise $\overline{\mathrm{X}}=34,34$ olduğu görülmektedir. Öğretmen adaylarının tarihî ve kültürel değerlere ilişkin tutum toplam puanları aritmetik ortalaması ile öğrenim gördükleri anabilim dalında Kırşehir ve yöresine yönelik gezi düzenlenme durumu arasındaki ilişki incelenmiş ve anlamlı bir farklılık gözlenmemiştir $\left(\mathrm{t}_{(321)}=, 933 ; \mathrm{p}>\right.$.05). Bu bulgu katılımcıların tarihî ve kültürel değerlerle yönelik tutumlarında öğrenim gördükleri anabilim 
dalında Kırşehir ve yöresine yönelik gezi düzenlenme faktörünün belirli bir etkiye sahip olmadığ 1 şeklinde yorumlanabilir.

\section{Sonuç ve Öneriler}

Çalışmanın sonuçları bölüm bazında incelendiğinde Kırşehir'in tarihî ve kültürel değerlerine yönelik sosyal bilgiler öğretmenliği anabilim dalında öğrenim gören öğretmen adaylarının sınıf öğretmenliği anabilim dalında öğrenim gören öğretmen adaylarına göre tutum puanlarının yüksekliği sosyal bilgiler öğretmen adaylarının coğrafya derslerini daha fazla görmüş olmaları ve aynı zamanda turizme yönelik dersleri de daha fazla görmeleriyle açıklanabilir. Katılımcıların Kırşehir'in tarihî ve kültürel değerlerine yönelik toplam tutum puanlarının cinsiyete göre değişmediği görülmüştür. Bu sonuç Dinç vd., (2011), Çetin ve Akkaya (2013) ile Karakuş vd., (2011) tarafından yapılan araştırmaların sonuçları ile benzerlik göstermektedir.

Araştırmaya katılan öğrencilerin Kırşehir'in tarihî ve kültürel turizm değerlerine yönelik tutumlarında; lisans eğitiminde turizmle ilgili ders alma durumunun, lisans eğitiminde turizmle ilgili sunum, ödev, proje vb. çalışma hazırlama ve öğrenim gördükleri anabilim dalında Kırşehir ve yöresine yönelik gezi düzenlenme durumlarının etkili olmadığı sonucuna ulaşılmıştır.

Öte yandan; her iki anabilim dalında öğrenim gören öğretmen adaylarından 4. Sınıftakilerin 2. Sınıfta öğrenim görenlere nazaran tarihî ve kültürel değerlerine yönelik tutumlarının yüksek düzeyde olması bu durumu destekler mahiyettedir. Çünkü hem sosyal bilgiler öğretmenliği hem de sınıf öğretmenliği anabilim dallarının 3. ve 4. Sınıflarında Turizme yönelik ders okutulmaktayken bu anabilim dallarının 2. Sınıflarında turizme yönelik herhangi bir ders okutulmamaktadır. Zaten yukarıda; turizme yönelik ders alma durumuna ilişkin bulguya da bakıldığında; turizme yönelik ders alanların sayısının almayanlara göre az olmasına rağmen aritmetik ortalama bakımından turizm dersi alanların tarihî ve kültürel değerlerine yönelik toplam puanlarının almayanlara göre yüksek olması turizme yönelik ders görmenin tarihi ve kültürel değerlere yönelik tutumları etkilemede belli bir etkiye sahip olduğunun kanıtıdır, denebilir.

Bu sonuçlardan hareketle;

Tarihi ve kültürel turizm değerlerinin hak ettiği değeri görmeleri ve geleceğin öğretmenleri olacak öğretmen adaylarının bunlara yönelik tutum ve farkındalıklarını artırmak adına eğitim fakültelerinde turizmle ilgili derslere ağırlık verilmesi gerektiği önerilmektedir. Bununla birlikte mevcut programlarında turizmle ilgili ders bulunan öğretim programlarında turizm 
derslerinin farklı sınıf düzeylerine yayılması önerilmektedir. Ayrıca lisans öğrencilerinin ve bu bağlamda öğretmen adaylarının üniversite dışında yapılan tarihi ve kültürel değerlere yönelik gezilere çoğu zaman maddi sıkıntılar nedeniyle katılamadıklarından hareketle gerek Kültür ve Turizm Bakanlığı tarafından gerekse üniversite yönetimleri tarafından desteklenmeleri gerektiği önerilmektedir. Araştırma soncunda eğitimöğretim sürecinin en kritik döneminde mesleklerini icra edecek olan sınıf öğretmen adaylarının tarihi ve kültürel turizm değerlerine yönelik tutum puanlarının düşük çıkmasından hareketle bu anabilim dalındaki öğretmen adaylarının akademik danışmanlarının veya ilgili derslerine giren öğretim elemanlarının ilgili öğrencilerin gerek ülkemizin gerekse hayatlarının en az dört yılını geçirecekleri bir süreçte eğitim gördükleri şehrin tarihî ve kültürel dokusunu öğrenmelerine yönelik girişimlerde bulunmaları önerilmektedir.

Doğal ve kültürel değerlere ilişkin bilgi ve farkındalık düzeyinin geliştirilmesinin Milli Eğitim Bakanlığınca hazırlanan Öğretmen Yeterlilikleri'nde de yer aldığı dikkate alınırsa bu değerlerin tarih ve coğrafya bilgisi dışında genel kültür bilgisini de arttırdığı için öğretmen adaylarına bu konuların kavratılması önem taşımaktadır. Bu bağlamda ortaokullardaki ve üniversitelerdeki öğretmen yetiştiren programlarda yer alan doğal ve kültürel turizme yönelik derslerin ve kazanımların sayısını arttırabilir.

\section{Kaynakça}

Aydın, İ. (1990). Açıklamalı Turizm Terimler Sözlüğü. Aydın: Coşkun Matbaası.

Barutçugil, İ.(1986). Turizm Ekonomisi ve Turizmin Türk Ekonomisindeki Yeri. İstanbul: Beta Basım Yayın Dağıtım.

Bulu, M. ve Eraslan, H. (2008) Bolu İli Turizm Sektörünün Uluslararası Rekabetçilik Analizi, http://www.urak.org/yayinlar/2008BuluveEraslan.pdf adresinden 15.12.2012 tarihinde alınmıştır.

Büyüköztürk, Ş. (2007). Sosyal Bilimler İçin Veri Analizi El Kitabl, Ankara: Pegem A Yayıncilık.

Çetin, T. (2010). Cumalıkızık Köyünde Kültürel Miras ve Turizm Algısı. Milli Folklor Dergisi, 22(87):181-190.

Çetin, T. ve Akkaya, M. (2013). The Awareness of the University Students about of the Cultural Heritage and the Touristic Values of Turkey in Unesco 
World Heritage List. The Science and Education at The Beginning of The 21st Century in Turkey Volume: 2 (Geography), St. Kliment Ohridski Universitesi Yayınları, Sofya, s. 641-660.

Dinç, E., Erdil, M. ve Keçe, M. (2011) Uşak üniversitesi öğrencilerinin tarihi ve kültürel eserler hakkındaki ilgi ve farkındalıklarının incelenmesi, Uşak Üniversitesi Sosyal Bilimler Dergisi, 4(2):267-285.

Doğanay H. (2001). Türkiye Turizm Coğrafyası, Konya: Çizgi Kitabevi.

Doğaner, S. (2001). Türkiye Turizm Coğrafyası, İstanbul: Çantay Kitabevi.

Doğaner, S. (2003). Miras Turizminin Coğrafi Kaynakları ve Korunması İzmir: Coğrafi Çevre Koruma Turizm Sempozyumu (16-18 Nisan 2003) Bildiri Kitab1, s.1-8.

Ehtiyar, R ve Üngüren, E. (2008). Turizm Eğitimi Alan Öğrencilerin Umutsuzluk ve Kaygı Seviyeleri ile Eğitime Yönelik Tutumları Arasındaki İlişkinin Belirlenmesine Yönelik bir Araştırma. Uluslararası Sosyal Araştırmalar Dergisi,1(4), (http://www.sosyalarastirmalar.com/pdf adresinden $\quad 13.12 .2012$ tarihinde alınmıştır.

Emekli, G. (1998). Bergama'da Turizm ve Sosyoekonomik Etkileri, Yayınlanmamış Doktora Tezi, İzmir: Ege Üniversitesi.

Emekli, G. (2005). Avrupa Birliği'nde Turizm Politikaları ve Türkiye'de Kültürel Turizm, Ege Coğrafya Dergisi, 14:99-107.

http://www.kirsehirkulturturizm.gov.tr/TR,64747/genel-bilgiler.html adresinden 28.09.2013 tarihinde alınmıştır.

İncekara, S. ve Savran, Z. (2011). Ortaöğretim öğrencilerinin turizme bakış açısının değerlendirilmesi üzerine bir çalışma: Hatay ili örneği, Marmara Coğrafya Dergisi, 23:144-164.

Kahraman N., Türkay, O. (2006). Turizm ve Çevre, Ankara: Detay Yayıncılık.

Karakuş, U., Çepni, O. ve Kılcan, B. (2011). İlköğretim ikinci kademe öğrencilerinin turizme yönelik görüşlerinin çeşitli değişkenler açısından incelenmesi (Safranbolu'da nicel bir çalışma). Pegem Ĕ̆itim ve Öğretim Dergisi, 4:85-95.

Karakuş, U., ve Çetin, T (2003). Jeotermal Enerjinin Kullanım Alanları ve Kırşehir Örneği. Türkiye Sosyal Araştırmalar Dergisi, 7 (2):9-25. 
Karasar, N. (2011). Bilimsel Araştırma Yöntemi. Ankara: Nobel Akademik Yayıncılık Eğitim Danışmanlık Tic. Ltd. Şti.

Keçe, M. ve Dinç, E. (2010) Öğretmen adaylarının tarihi ve kültürel eserler hakkındaki ilgi ve farkındalıklarının incelenmesi, I. Uluslararası Tarih Ĕ̈itimi Sempozyumu, (16-18 Haziran 2010), Erzurum.

Kozak, N., Kozak, M.A., ve Kozak, M. (2011). Genel Turizm (Ilkeler-Kavramlar). Ankara: Detay Yayıncilık.

Meydan Uygur, S., Baykan E.(2007). Kültür Turizmi ve Turizmin Kültürel Varlıklar Üzerindeki Etkileri. Ticaret ve Turizm Eğitim Fakültesi Dergisi 2:30-49.

Oğuz, Ö. (2002). Küreselleşme ve Uygulamalı Halkbilimi. Ankara: Akçağ Yayınevi.

Özgüç N. (2003). Turizm Coğrafyası Özellikler ve Bölgeler, İstanbul: Çantay Kitabevi.

Öztürk, Y., Yazıcıoğlu, İ. (2002). Gelişmekte Olan Ülkeler için Alternatif Turizm Faaliyetleri Üzerine Teorik Bir Çalışma. Gazi Üniversitesi Ticaret ve Turizm Eğitim Fakültesi Dergisi, 2: 183-195.

Sezgin, M, (1995). Genel Turizm, Ankara: Tutibay Ltd. Şti.

Soykan F. (2004). Kırsal Turizm ve Türkiye Turizmi İçin Önemi. Ege Coğrafya Dergisi, 12):1-11.

Tok, C. (2002). Kültür Turizmi, T.C.Turizm Bakanlığı II. Turizm Şurası Bildirileri, 12-14 Nisan 2002, Ankara.

Usta, N, (2012). İnanç Turizminden Kültür Turizmine: Midilli Adası'nın Agiasos Dă̆ Köyü Örneği, KMÜ Sosyal ve Ekonomik Araştırmalar Dergisi, 14 (22): 163-168, 2012.

Ürger, S, (1992) Genel Turizm Bilgisi, Antalya: Akdeniz Üniversitesi, Turizm İşletmeciliği ve Otelcilik Yüksekokulu.

Yıldız, Z, Kalağan, G. (2005) Alternatif Turizm Kavramı ve Çevresel Etkileri, Yerel Siyaset Dergisi, http://www.yerelsiyaset.com/pdf/kasim2008/9. pdf adresinden 17.12.2012 tarihinde alınmıştır. 